William E. Leuchtenberg, The Perils of Prosperity, 1914-32 (Chicago: University Press, Chicago History of American Civilization series, 1958; C.U.P., 26s.). Pp. ix, 313.

Duane Lockard, New England State Politics (Princeton: University Press, 1959; O.U.P., 48s. . Pp. viii, 348.

John D. Martz, Central America: the Crisis and the Challenge (Chapel Hill: University of North Carolina Press, 1959; 0.U.P., 60s.). Pp. ix, 356. Maps. Covers modem Guatemala, El Salvador, Honduras, Nicaragua, Costa Rica and Panama.

Robert $v$. Remini, Martin Van Buren and the Making of the Democratic Party (New York: Columbia University Press, 1959; 0.U.P., 40s.). Pp. viii, 271.

George Dearborn Spindler, The Transmission of American Culture. A William Ho Burton Lecture (Cambridge: Harvard University Press, 1959; 0.U.P., 12s.). Pp. $x, 51$.

Orville W. Taylor, Negro Slavery in Arkansas (Durham: Duke University Press, 1958; C.U.P., 45s.). Pp. viii, 282. Illustrated.

*Frank Thistlethwaite, The Anglo-American Connection in the Early Nineteenth Century (Philadelphia: Pennsylvania University Press, 1959; 0.U.P., 36s.). Pp. viii, 222.

Richard C. Wade, The Urban Frontier: the Rise of Western Cities, 1790-1830

(Cambridge: Harvard University Press, 1959; 0.U.P., 48s.).

\title{
NEWS OF MEMBERS
}

\section{Old Members}

Mr. David Adams (University College of North Staffordshire) is acting as part-time lecturer in American history at Manchester University during Mr. Marcus Cunliffe's absence in the United States.

Mr. Michael Brook (University of Southampton) reports that the University of Southampton is still continuing its successful Extra-Mural course on American history, in which visiting Arerican lecturers are a notable feature.

Mr. Alan Conwgy (University College of Wales, Aberystwyth) reports that the History Denartment at Aberystwyth has started a Special Subject on "Reconstruction". A grant of three thousand dollars from the Rockefeller Foundation helped to make this possible. The new Special subject has been well received by final-year Honours History students at Aberystwyth.

Mr. Marcus Cunliffe is deputising for Professor Frank Feidel at Harvard during the Academic Year 1959-60. 'Among the courses he will be offering is a particularly interesting one on civilian-military relations in the United States from 1775-1865. He also expects to give a paper on "American $\Lambda$ ttitudes to the Past: a European View" to the Anerican Historical Association meeting at Chicago in December 1959. From I September, 1959, to I July, $1960 \mathrm{Mr}$. Cunliffe's address will be 9 Maynard Place, Cambridge 38, Massachusetts, U.S.A. (telephone number, Eliot 4-3897).

Members of the British Association for American Studies will wish to of fer their congratulations to Mr. Cunliffe on his appointment as first Professor of American History and Institutions at the University of Manchester.

Dr. J. Gold has finisined his Ph.D. at the University of Wisconsin on William Faulkner. During the Academic Year 1959-60 he will be Assistant Professor of English at Whitewater State College, Wisconsin. Modern Fiction Studies has accepted an article of his on Faulkner's The Fable for publication in 1960 . 
Mr. James A. Hart is a Ph.D. candidate in American Literature at Duke University, where he holds a James B. Duke fellowship. He is investigating the reaction of American poets to the First World War. His American address is 909 Clarendon Street, Durham, N.C..

Mr. Andrew Hook (formerly of the University of Edinburgh and the University of Manchester) is working for his doctorate at Princeton on cultural relations between Scotland and America, 1763-1830.

Dr. Henry Pelling (The Queen's College, Oxford) spent March-September in the United States, mainly at the University of Wisconsin, where he completed a volume for the Chicago University Press "History of American Civilization" series on American Labour. This is scheduled for publication in the spring of 1960 . Oxon..

Mr. Dennis S. Porter has changed his address to 3 Field Close, Yamton,

Many B.A.A.S. members will have very pleasant memories of Dr. Myron $L$. Koenig, formerly U.S. Cultural Attaché in London, whose practical encouragement to the Association when it was formed has proved invaluable. Dr. Koenig is now Associate Dean of the School of Foreign Affairs, Foreign Service Institute, Washington D.C.. Dr. Kounig sends his warmest wishes to all B.A.A.S. members whom he grew to know so well during his period in Great Britain.

\section{Publications}

(See also "Other publications received", page 31.)

H. C. Allen, Bush and Backwoods (London: Angus and Robertson, 1959, 25s.). P.p. vii, 153. A comparative study of the American and Australian frontier.

Max Beloff, The Great Powers. Essays in Twentieth Century Politic's (London, 1959). Part III of this collection contains seven essays on American themes, particularly "Theodore Roosevelt and the British Enpire", a lecture delivered at Rhodes House, Oxford, 23 May, 1958, at the request of the Theodore Roosevelt Centennial Commission of New York.

Alan Conway, "The Sacking of Lawrence", The Kansas Historical Quarterly, XXIV, 2, Summer, 1958.

Marcus Cunliffe, George Washington. Man and Monument (London, 1958).

Marcus Cunliffe, The Nation Takes Shape. 1789-1837 (Chicago: University Press, 1959; Chicago "History of American Civilization" series).

Geoffrey Moore, "Sinclair Lewis: a Lost Romantic" in The Young Rebel in American Literature (London: 1959), edited by Carl Bode.

Frank Thistlethwaite, "The Atlantic Migration of the Pottery Industry", Economic History Review, XI, 2, 1958, pp. 264-278.

\section{New-Members}

Mrs. Miriam Alman: formerly bibliographical assistant for the Survey of Sources for American Studies in Great. Britain. Address: 42 Portman Mansions, Baker Street, London, W. I.

Mr. J.R. Avery, M.A.(Oxon.): from January 1960 will be Senior History Master at Haberdashers' Aske's School, Hampstead, London; he visited the United States in 1945.

Mr. Gordon Edward Connell-Smith, B.A., Ph.D.(London): at present Staff Tutor in History and International Affairs, University of Hull; also lectures. in Hull University History Department on the diplomatic history of the United States. Mr. Connell-Smith's publications include Forerunner of Drake. A 
Study of English Trade with Spain in the Early Tudor Period. (London, 1954); Pattern of the Post-War World ("Penguin", London, 1957); "English Merchants trading to the "New World in the Early Sixteenth Century", Bulletin of the Institute of Historical Research, XXIII, 67, May, 1950; "The Ledger of Thomas Howell", Economic History Review, III, 3, 1951; "Summary of the Julian Corbett Prize Essay", Bulletin of the Institute of Historical Research, XXIV, 69, May, 1951; "Roberto Reneger, Precursor de Drake", Annario de Estudios Americanos, VII, Seville, 1950. He is preparing a work on The Inter-American System, to be published under the auspices of the Royal Institute of International Affairs. Address: Flat 4, Shardelocs, Newgate Street, Cottingham, Yorkshire.

Mr. John Day: at present Assistant Lecturer in Politics, University of Leicester; formerly fssistant Lecturer in History, University of Edinburgh; has spent a year at Harvard, and is interested in all aspects of American politics; has published an article in The Naw Yorker.

Mr. Eric N. W. Mottram, M.A. (Cantab.): at present Lecturer in American Literature, King's College, London University; is preparing a book on the deliberate manipulation of character towards preplanned fate in American fiction of the last helf century. Address: 33 Norfolk Square, Brighton, Sussex.

\section{BRUERN FOUNDATION AWARD}

by Anthony $\mathrm{H}$. Allt

An award of $\$ 1250$ for a month's travel in the United States was made in May, 1959 to Miss C. M. Pearson, Headmistress of the High School for Girls, Wednesbury; Mr. A. Forbes, Senior History Master of Fraserburgh Academy; and Mr. A. H. Allt; Senior History Master of Varndean Grammar School for Boys, Brighton. This award took effect from September 22nd to October 15th of this year.

In so far as there were no strings attached to this generous award, we were given a very free hand in choosing our itinerary, within the general framework of a proposed week in Washington at first, with a week in Now York at the end of our stay, spent together, with ten days of individual travel between. This time was spent by Miss Pearson in Louisville, Kentucky, and Chicago; by Mr. Forbes in Niagara Falls, Boston, Harvard and Yale Universities, and Hartford, Connecticut; and by Mr. Allt in Richmond, Charleston, Philadelphia and Princeton. Our journey was made under the joint auspices of the Institute of International Education and the Federal Department of Health, Welfare and Education; more particularly in the hands of Miss Barbara Godard of the I.I.E. In New York City, and Dr. Paul Bodenman of the Federal Department in Washington. These two bodies made every effort to ensure that we saw what we wanted to, and nodifications, even at the last minute, were chesrfully agreed. All travel arrangements hotel accommodation, air passages, bus and train bookings - had been mado in advance, and were an important factor in making our trip free from anxiety. was always a good thing to check up on air passages shortly before undertaking them, as we had been warned. The standard of hotel accommodation was high, not to say luxurious in many cases. We would like to express our appreciation of the work done by Miss Godard and her staff in this connection. Dr. Bodenman had arranged that we had a sponsor in each of the principal cities we visited, so that we always had a point of contact on arrival. In most cases this was the local superintendent of Schools, each of whom saw to it that we were looked after during our stay in his area. This system had great advantages in that the sponsors put themselves to much trouble to ensure local co-operation and access to places of interest and to the schools under their control. In some cases the superintendent himself, his Deputy, or a member of the Boord of. Education office staff were our guides round places of historic interest within their city, and even to battlefields fifty-six miles away in the case of Richmond. The history master of Gettysburg High School had the day off specifically to conduct us round the battlefield - in the school car. Some real friendships were made in this way. 